\title{
Pengaruh Ukuran Serbuk Terhadap Karakteristik Rendaman Serbuk Daun Azadirachta Indica Dalam Minyak Zaitun
}

\section{Effect Of Powder Size On Characteristic Azadirachta Indica Leaves Of Immersion On Olive Oil}

\author{
M. Eko Pranoto, Diana Lady Yunita Handoyo \\ Program Studi Farmasi, Fakultas Ilmu Kesehatan, Universitas Ibrahimy \\ Email: ekopranoto@ibrahimy.ac.id
}

\begin{abstract}
ABSTRAK
Nimba (Azadirachta indica) dikenal sebagai anti insektisida yang dapat berpengaruh pada kurang lebih 400 jenis serangga. Nimba banyak tumbuh di indonesia dan mudah dijumpai sehingga digunakan oleh masyarakat sebagai insektidsida nabati. Metode pengolahan secara sederhana pada pemanfaatan daun mimba diperlukan sehingga dapat dengan mudah diterapkan oleh masyarakat. Perlakuan pendahuluan yang dapat dilakukan sebelum dilakukan perendaman salah satunya pengecilan ukuran partikel (penggilingan). Penelitian ini bertujuan untuk mengetahui pengaruh ukuran serbuk terhadap karakteristik fisik minyak rendaman daun Nimba. Dengan mengamati hasil rendaman dalam minyak zaitun serbuk Nimba yang telah diayak menggunakan ayakan 40, 60 dan 80 mseh. Hasil yang diperoleh menunjukkan ukuran serbuk mempengaruhi warna, kejernihan dan aroma minyak hasil rendaman. Ukuran serbuk juga berpengaruh secara bermakna pada bobot jenis hasil rendaman. Minyak rendaman serbuk daun Nimba yang diayak menggunakan ayakan 80 mesh memiliki warna hijau kehitaman, pekat dan bau khas nimba serta bobot jenis sebesar 0,907 g/ml.
\end{abstract}

Kata Kunci : Daun Nimba, Ukuran Serbuk, Perendamana, Minyak Zaitun, Organoleptis.

\section{ABSTRACT}

Neem (Azadirachta indica) is known as an anti-insecticide that can affect approximately 400 species of insects. Neem is widely grown in Indonesia and easily found so it is used as a vegetable insecticide. Simple processing methods are needed so they can be easily applied. Preliminary treatment that can be done before immersion is one of them is reduction in particle size (grinding). This study aims to determine the effect of powder size on the physical characteristics of neem leaf immersion oil. By observing the results of immersion in olive oil Nimba powder leaf that has been sifted using 40, 60 and 80 mesh sieves. The results obtained show the size of the powder affects the color, clarity, aroma and specific gravity. Immersion oil of Neem leaf powder which sifted using 80 mesh sieve has blackish green color, concentrated and characteristic odor of neem and specific gravity of $0.907 \mathrm{~g} / \mathrm{ml}$.

Keyword : Neem Leaf, Powder Size, Immersion, Olive Oil, Organoleptic.

\section{PENDAHULUAN}

Tanaman nimba (Azadirachta

indica), merupakan salah satu tanaman

yang banyak ditemui dan memiliki

efektivitas sebagai anti serangga.
Tanaman mimba banyak digunakan sebagai insektisida nabati karena memiliki salah satu zat aktif berupa azadirachtin. Mimba juga dapat dipilih sebagai anti-kutu yang relatif aman. 
Azadirachtin dalam daun mimba merupakan senyawa golongan tetranortriterpenoid yang memiliki ektivitas sebagai anti serangga. Senyawa azadirachtin dapat menghambat pertumbuhan, mengurangi nafsu makan, mengurangi produksi dan penetasan telur, meningkatkan mortalitas serangga (Maragathavalli, et al., 2012). Selain Azadirachtin pada nimba juga terdapat kandungan salanin, meliatriol, dan nimbin yang memiliki aktivitas sebagai pestisida (Debashri dan Tamal, 2012).

Metode pengolahan secara sederhana pada pemanfaatan daun mimba diperlukan sehingga dapat dengan mudah diterapkan oleh masyarakat. Salah satu metode tradisional yang dapat diterapkan yakni seperti pada pembuatan minyak rempah yakni dengan merendam bahan pada minyak dengan menggunakan pemanasan. Pelarut jenis minyak dipilih sebagai bahan perendam karena merupakan bahan yang mudah ditemui dan diperoleh oleh masyarakat serta penggunaannya relatif aman dibandingkan pelarut-pelarut organik. Selain itu minyak dapat menahan zat lebih lama di kepala dan hasil rendaman

dapat langsung digunakan tanpa memerlukan proses lanjutan.

Perlakuan pendahuluan yang dapat dilakukan sebelum dilakukan perendaman diantarnya pengeringan, dan pengecilan ukuran partikel (penggilingan). Pada proses pengeringan akan menyebabkan adanya proses pelepasan air dari bahan. Hal ini akan menyebabkan pecahnya sel-sel minyak sehingga zat akan lebih mudah terpenetrasi pada pelarut (Ma'mun, 2009). Sedangkan, tujuan pengecilan ukuran untuk menambah luas permukaan bahan sehingga minyak yang dihasilkan lebih banyak (Ketaren, 1993)

Variasi ukuran partikel pada bahan mimba dapat mempengaruhi terhadap karakteristik fisika maupun kimia hasil rendaman. Sehingga adanya percobaan untuk mengamati pengaruh ukuran serbuk terhadap karakteristik hasil rendaman perlu dilakukan. Hal ini yang melatarbelakangi penelitian untuk mengetahui pengaruh variasai ukuran serbuk (40 mesh, 60 mesgh dan 80 mesh) terhadap karakteristik fisik rendaman daun mimba dalam minyak kemiri. Dalam penelitian ini minyak rendaman akan diamati warna, kejernihan, aroma serta berat jenisnya. 
Daun tanaman nimba memiliki senyawa golongan terpenoid, flavonoid, alkaloid, saponin, dan tanin (Biu et al, 2009). Menurut Aslam et al. (2009) daun tanaman nimba memiliki kandungan senyawa steroid dan triterpenoid. senyawa terpenoid bersifat lipofilik dengan merusak membran sel bakteri dan organisme (Cowan, 1999). Senyawa terpenoid yang terkandung dalam tanaman nimba merupakan senyawa triterpenoid antara lain azadirachtin $a, \quad$ azadirachtin $b$, azadirachtin $d, \quad$ azadirachtin $h$, azadirachtin $i, \quad$ desacetylnimbin, azadiradione, nimbin, salanin, azadirone, nimbolin, nimbinene, dan nimbolide. Senyawa golongan tritepenoid yang tidak terkandung dalam daun yakni nimono dan epoxyazadirodione.

Tanaman nimba sudah sejak lama telah digunakan sebagai insektisida nabati karena memiliki kemanjuran dan peruntukan yang luas (broad spectrum), baik digunakan secara sederhana maupun dengan formula baru. Di Indonesia, tanaman nimba sudah digunakan untuk mengendalikan organisme tanaman pengganggu (OTP) baik pada tanaman pangan maupun non pangan (Kardinan dan Dhalimi, 2003).
Cara kerja senyawa aktif pada tanaman nimba tidak membunuh hama secara cepat, tetapi dapat mempengaruhi daya makan, pertumbuhan dan daya reproduksi. Selain itu, senyawa aktif pada tanaman nimba dapat mempengaruhi proses ganti kulit, menghambat perkawinan, daya tetas telur, dan menghambat pertumbuhan kitin, dan sebagai pemandul (Schmutter and Singh, 1995). Senyawa aktif pada tanaman nimba dapat berpengaruh terhadap lebih kurang 400 jenis serangga (Howatt, 1994).

Azadirachtin yang terkandung dalam tanaman nimba dapat menghambat kerja hormon ecdyson yang berfungsi dalam proses pergantian kulit, ataupun proses metamorfosa kutu, yakni proses perubahan dari telur menjadi larva, atau dari larva menjadi kepompong atau dari kepompong menjadi dewasa.

Minyak zaitun diperoleh dari buah zaitun yang telah matang berwarna ungu kehitaman yang kemudian diekstrak untuk diambil minyakny. Zaitun mengandung alkaloid, saponin, dan tannin, tapi tidak mengandung sianogenik glikosid. Dalam beberapa riset juga menemukan adanya flavonoid 
apigenin, luteolin, chryseriol dan derivatnya (Fehri et al, 1996).

\section{METODE PENELITIAN}

Penelitian ini merupakan penelitian eksperimental dengan desain kualitatif deskriptif. Penelitian dilakukan di Laboratorium Kimia Dasar, Prodi Farmasi, Fakultas Ilmu Kesehatan, Universitas Ibrahimy pada Bulan Februari-Agustus 2019.

Bahan yang digunakan dalam penelitian ini adalah daun nimba yang diperoleh dari sekitar Kabupaten Situbondo, minyak zaitun murni impor yang diproduksi oleh Borges Agricultural \& Industrial Edible Oils, Spanyol.

Alat yang digunakan antara lain, neraca analitik, beaker glass, gelas ukur, pipet tetes, hot plate, sieve shaker dengan ukuran ayakan 40, 60 dan 80 mesh, piknometer. Perlakuan pendahuluan yang dilakukan adalah sebaiberikut, mimba yang sudah dipetik dipilih dan dibersihkan dari pengotornya, mimba selanjutnya dicuci bersih, kemudian dibiarkan hingga tidak ada air yang menetes. Selanjutnya daun mimba dipetik dan dipisahkan dari batang maupun tangkai daun. Daun mimba hasil sortasi kemudian dikeringkan dengan,. Pengeringan daun mimba dilakukan dalam ruangan dan tidak terpapar sinar matahari langsung. Daun mimba dikeringkan hingga kadar airnya tidak melebihi $10 \%$ atau secara visual daun patah saat diremas namun tidak hancur. Daiun mimba yang telah kering selanjutnya dihaluskan menggunakan mesin penggiling. Daun mimba yang telah digiling kemudian diayak menggunakan sieve shaker dengan ukuran ayakan 40, 60 dan 80 mesh.

Serbuk daun nimba yang lolos dari ayakan 40, 60 dan 80 mesh masingmasing ditimbang dengan jumlah yang sesuai. Bobot serbuk yang akan direndam sebanyak $10 \%$ dari volume minyak. Minyak yang telah berisi serbuk daun mimba dipanaskan dengan suhu dibawah $60^{\circ} \mathrm{C}$ selama 1 jam dengan sesekali dilakukan pengadukan. Setelah pemanasan selama 1 jam, rendaman diangkat dari pemanas dan didiamkan selama 24 jam. Masingmasing rendaman pada tiap ukuran serbuk dibuat sebanyak tiga replikasi. Setelah 24 jam, hasil rendaman disaring menggunakan kain saring kemudian disimpan dalam tople kaca untuk selanjutnya diamati. 
Hasil rendaman diamati organoliptiknya meliputi warna, bau, kejernihan dan bobot jenisnya. Penentuan berat jenis pada minyak hasil rendaman dilakukan menggunakan piknometer dengan tiga kali replikasi yang kemudian dianalisis menggunakan ANOVA.

\section{HASIL DAN PEMBAHASAN}

Pengamatan organoleptis pada hasil rendaman serbuk daun Nimba ditampilkan pada tabel 1 .

Tabel 1. Hasil Pengamatan Organoleptis Rendaman Daun Nimba.

\begin{tabular}{cccc}
\hline $\begin{array}{c}\text { Ukuran } \\
\text { Mesh }\end{array}$ & Warna & Bau & Kejernihan \\
\hline 40 & Hijau & $\begin{array}{c}\text { Khas } \\
\text { Nimba }\end{array}$ & Jernih \\
60 & $\begin{array}{c}\text { Hijau } \\
\text { kecoklatan } \\
\text { Hijau }\end{array}$ & $\begin{array}{c}\text { Nimba } \\
\text { Khas } \\
\text { Nehitaman }\end{array}$ & Jernih \\
Nimba & Pekat \\
\hline
\end{tabular}

Hasil rendaman pada serbuk hasil ayakajn 40 dan 60 mesh memiliki tampilan organoleptis yang hampir sama, namun hasil rendaman serbuk hasil ayakan 60 mesh tampak lebih kecoklatan dibanding hasil ayakan 40 mesh. Sedangkan untuk serbuk hasil ayakan 80 mesh tampak berbeda baik dari warna maupun kejernihan serta memiliki aroma khas nimba yang lebih kuat.
Selanjutnya hasil pengukuran berat jenis pada masing-masing rendaman ditampilkan pada tabel 2 .

\begin{tabular}{cc} 
Tabel 2. Bobot Jenis Minya Rendaman. \\
\hline Ukuran Mesh & Berat Jenis (g/ml) \\
\hline 40 & $0,88300 \pm 0,007$ \\
60 & $0,89167 \pm 0,003$ \\
80 & $0,90700 \pm 0,003$ \\
p-value & 0,002 \\
\hline
\end{tabular}

Hasil uji statistik ANOVA, menunjukkan adanya perbedaan yang bermakna dari nilai berat jenis pada masing-masing hasil rendaman yang ditunjukkan dengan nila $\mathrm{P}$ yang kurang dari 0,05. Data tersebut menunjukkan pengecilan ukuran serbuk meningkatkan bobot jenis dari minyak rendaman.

Adanya pengecilan pertikel akan memperluas area kontak bahan dengan minyak. Hal ini memungkinkan semakin banyak komponen pada serbuk daun yang terbawa dalam minyak perendam. Sehingga semakin banyak konsentrasi zat yang terbawa dalam minyak akan meningkatkan bobot jenis minyak (Reineccius, 1994). Hal ini juga yang menyebabkan hasil rendaman memiliki aroma yang lebih kuat dibanding ukuran mesh yang lain. 


\section{SIMPULAN DAN SARAN}

Pengecilan partikel serbuk daun Nimba yang direndam menggunakan minyak zaitun mempengaruhi tampilan organoleptik dan bobot jenis minyak. Semakin kecil ukuran serbuk akan menghasilkan warna rendaman yang semakin gelap, semakin pekat serta aroma khas nimba yang semakin kuat. Pengecilan partikel juga meningkatkan nilai berat jenis dari minyak perendam secara signifikan. Serbuk daun nimba yang diayak menggunakan ayakan 80 mesh dan direndam dalam minayk zaitun, menghasilkan rendaman berwarna hijau kehitaman, pekat dan aroma khas nimba yang kua dengan bobot jenis 0,907 $\mathrm{g} / \mathrm{ml}$. Pengujian kandungan pada hasil perendaman dapat menjadi tema lanjutan pada penelitian ini. Sehingga dapat diketahui pengaruh ukuran serbuk terhadap zat-zat yang terkandung dalam daun nimba

\section{DAFTAR PUSTAKA}

Aslam, F., Khalil-ur-Rehman, Asghar, M., and Sarwar. M., 2009, Antibacterial Activity of Various Phytoconstituents of Neem. Pakistan Journal Agricultural Science 46 (3).

Biu, A.A., S.D. Yusufu, and J.S. Rabo. 2009. Phytochemical screening of Azadirachta indica (Neem) (Meliaceae) in Maiduguri,
Nigeria. Bioscience Research Communications 2009.

Cowan, M. M. 1999. Plant Products as Antimicrobial Agents. Clinical Microbiology Reviews, 12(4) 1999.

Fehri, B., Aiache, J.M., Mrad, S., Korbi, S., and Lamaison, J.L. (1996). Olea Europea L : Stimulant, antiulcer, anti-inflamatory effects. Boll. Chim. Pharm. 135 (1): 4249. [serial on line]. http://www.plantzafrica.com/med monographs/oleaeuropafric.pdf. Diakses pada 20 Maret 2019.

Kardinan, A dan A. Dhalimi. 2003. Mimba (Azadirachta indica Juss) Tanaman Multi Manfaat. Perkembangan Teknologi TRO. Vol XV. No.1.2003. Ketaren, S. 1993. Pengantar Minyak Atsiri Jilid II. Balai Pustaka. Jakarta.

Kosalge, S. B. dan Fursule, R. A., 2009. Investigation of Licidal Activity os Some Plants from Satpuda Hills. International journal of PharmTech Research CODEN (USA):IJPRIF V01.1 No. 3, pp.564-567.

Ma'mun, B.S., dan Shinta, S. 2009. Karakteristik Minyak Atsiri Potensial. Balai Penelitian Tanaman Obat dan Aromatik. Bogor.

Maragathavalli, S., Brindha, S., Kaviyarasi, N. S., Annadurai, B. \& Gangwar, S. K. 2012. Mosquitoes Larvicidal Activity Of Leaf Extract of Neem (Azadirachta indica). International Journal Of Advanced Biological Research 
Vol. 2(1) 2012:138-142 ISSN $2250-3579$.

Reineccius, G. 1994. Flavor Chemistri. Di dalam : Hidayat, F. K. 1999. Ekstraksi Minyak Atsiri Dari Daun Jeruk Purut (Citrus hystrix DC) pada Skala Pilot-Plant. Sripsi. Jurusan Teknologi Pangan dan Gizi Fakultas Teknologi Pertanian Institut Pertanian Bogor. Bogor
Schmutter, H. \& R.P. Singh. 1995. List of Insect Pest Suspectible to Neem Products. In H. Schmutter (ed.). The Neem Tree-Source of Unique Natural Products for Integrated Pest Management, Medicine, Industry and Other Purposes. Pp. 326-365. VCH, Weinheim, New York, Basel, Cambridge, Tokyo. 